\title{
Onset of Canonical Babbling in Children with and without Cleft Palate
}

\author{
Seunghee Ha \\ Division of Speech Pathology and Audiology, Audiology and Speech Pathology Research Institute, Hallym University, Chuncheon, Korea
}

Correspondence: Seunghee Ha, PhD Division of Speech Pathology and Audiology, Audiology and Speech Pathology Research Institute, Hallym University, 1 Hallimdaehak-gil, Chuncheon 24252, Korea

Tel: +82-33-248-2215

Fax: +82-33-256-3420

E-mail: shha@hallym.ac.kr

Received: July 4, 2019

Revised: August 19, 2019

Accepted: August 19, 2019

This research has been supported by Hallym University Research Fund (No. HRF-201906-007).

\begin{abstract}
Objectives: The emergence of canonical babbling reflects a critical advance in development of speech capacity in the first year, and late onset of canonical babbling appeared to be a predictor of later speech and language disorders. This study aimed to examine characteristics and changes in canonical babbling in children with and without cleft palate (CP) using all-day recordings in naturalistic environments. Methods: All-day home recordings using Language ENvironment Analysis (LENA) were obtained from 9 children with CP and 9 children without $\mathrm{CP}$ at four different time blocks from 4 to 21 months. Twenty 5-mintue segments with the highest child vocalization rate were extracted from each children's LENA recording. Coders classified syllables as canonical and non-canonical syllables, syllables with glottal sounds, and syllables with glides. Group and age comparisons were conducted in terms of the number of each syllable type and canonical babbling ratios (CBR) at observed times. Results: The results indicated that there were no significant group differences in total number of vocalization and syllables across the observed times. Children with CP produced fewer canonical syllables than children without $\mathrm{CP}$ at 13-15 months of age. The group differences in the CBR and true CBR were significant at 13-15 months and at 19-21 months. Conclusion: This study suggests that children with CP show late onset of canonical babbling and group difference in the quality of babbling became evident even after surgical repair. This study highlights the importance of early intervention for children with CP.
\end{abstract}

Keywords: Canonical babbling, Onset, Cleft palate, Naturalistic environments, Longitudinal study
아동이 생후 1 년 동안 산출하는 초기 발성 가운데 음절성 옹알 이(canonical babbling)는 최소 한 개 이상의 자음과 모음을 포함한 형태로, 이후 발달하는 낱말의 기본적인 구성요소를 이루면서 음 운능력의 기초가 된다. 음절성 옹알이를 구성하는 기본 음절(canonical syllable)은 모음에 해당하는 완전공명핵과 상후두 조음기 제(혀, 입술, 턱)의 움직임으로 만들어지는 자음 같은 소리를 포함 하고, 공명핵과 자음 같은 소리 사이의 포먼트 전이 구간이 짧은 것 이 특징이다(Oller, 2000). 일반아동은 보통 생후 4-6개월 이후부터 음절성 옹알이를 산출하기 시작하여 늦어도 10 개월 이전에는 대부 분이 음절성 옹알이를 산출한다(Lee, Jhang, Relyea, Chen, \& Oller, 2018). 음절성 옹알이의 이러한 시작 시기는 청각장애, 다운증후군, 구개열 등 청각-말 기제의 선천적인 결함을 가지고 태어난 아동과 일반아동이 뚜렷하게 차이를 보이면서 임상적으로 말-언어장애를
예측하는 중요한 지표로 보고되고 있다(Chapman, Hardin-Jones, Schulte, \& Halter, 2001; Cobo-Lewis, Oller, Lynch, \& Levine, 1996; Ertmer, Young, \& Nathani, 2007; Lynch et al., 1995).

Lynch 등(1995)은 다운증후군 아동을 대상으로 음절성 옹알이 의 시작과 발달패턴을 연구하면서 음절성 옹알이의 시작 시기를 조작적으로 정의내리고자 하였다. 전체 발성 중 음절성 옹알이의 구성성분인 기본음절의 비율이 $15 \%$ 이상일 경우 해당 아동은 음 절성 옹알이 단계에 진입한 것으로 평가하였고, 이후 음절성 옹알 이와 관련된 대부분의 연구에서는 Lynch 등(1995)의 기준을 사용 하고 있다. 아동의 전체 발성에서 음절성 옹알이의 기본 음절이 $15 \%$ 정도 차지할 경우 가정에서 부모가 아동의 음절성 옹알이를 쉽게 지각할 수 있으며 음절성 옹알이를 비교적 안정적으로 산출할 수 있는 단계에 있음을 의미한다. 최근 Ha와 Oller (2019)는 4-9개월 
한국 아동을 대상으로 언어환경분석기(Language ENvironmental Analysis, LENA)를 이용하여 아동의 자연스런 가정환경에서 하루 동안 수집한 자료를 토대로 음절성 옹알이를 살펴보았다. 연구결 과, 4-6개월 아동은 평균 $4.7 \%$ 로 음절성 옹알이의 기본음절 비율 이 비교적 낮았으나 7-9개월 아동은 평균 $15.9 \%$ 로 증가하는 발달 적인 추세가 나타났다. 선행연구의 $15 \%$ 의 기준을 토대로 자료를 살 펴보았을 때, 13명의 7-9개월 아동 중 8명이 음절성 옹알이 단계에 진입하였다.

구개열 아동은 연인두 기제상의 선천적인 결함과 반복적인 중이 염으로 인해 언어이전기 발성부터 일반아동과 다른 발달을 보인다. 구개열 아동은 초기 발성의 다양한 지표 중 음절성 옹알이의 시작 시기와 음절성 옹알이에 포함된 말소리목록 면에서 두드러진 차이 를 보인다. 생후 9 개월의 구개열과 일반아동을 대상으로 음절성 옹 알이의 시작 시기와 특징을 비교한 Chapman 등(2001)에서는 일반 아동의 $93 \%$ 가 음절성 옹알이 단계에 도달한 반면에 구개열 아동은 $57 \%$ 만이 음절성 옹알이 단계에 도달하였다. 또한 음절유형과 길이 면에서는 구개열과 일반아동이 유사하였지만 구개열 아동은 음절 성 옹알이에 성문음 비율이 높고 구강 자음의 비율과 목록이 유의 미하게 적었다. 한편 국내 Kim과 $\mathrm{Ha}$ (2013)의 연구와 $\mathrm{Ha}$ (2018)의 연구에서는 0-20개월 아동의 초기 발성 발달을 평가하기 위해 개발 된 Stark Assessment of Early Vocal Development-Revised (SAEVD-R; Nathani, Ertmer, \& Stark, 2006)를 이용하여 한국 구개열 아동과 일반 아동의 초기 발성을 종단적으로 살펴보았다. SAEVD$\mathrm{R}$ 은 아동의 초기 발성의 분석단위가 음절이 아닌 발화(utterance) 로 분석하면서, 초기 발성을 발달단계별로 5 단계와 23 개의 하위유 형으로 나누어 조작적 정의와 출현 시기를 제시하고 있다. SAEVD$\mathrm{R}$ 에서 음절성 옹알이는 4 단계와 5 단계에 포함되는데 4 단계는 하나 의 자음과 모음이 결합된 일음절이나 이러한 음절이 반복되는 반 복적 옹알이를 포함하고, 5 단계는 한 발화에 다양한 자음과 모음 이 결합된 변형적 옹알이나 자곤(jargon)을 포함하고 있다. 선행연 구에서 구개열 아동은 9 개월에서 18 개월 동안 4 단계와 5 단계의 비 율이 일반아동보다 유의미하게 낮고, 음절성 옹알이가 포함되지 않 은 1-3단계의 비율이 상대적으로 높은 것으로 나타났다. 선행연구 는 SAEVD-R이라는 체계적인 평가도구를 이용하여 수술 이후에 도 구개열 아동이 지속적으로 말 발달상의 문제를 보임을 입증하 였다. 선행연구는 구개성형술 전후로 구개열 아동의 초기 발성 발 달패턴을 종단적으로 살펴보았다는 데 의의가 있다. 하지만 Kim과 $\mathrm{Ha}$ (2013)는 너무 적은 대상자 수를 토대로 살펴보았고, $\mathrm{Ha}$ (2018) 는 많은 아동이 이미 음절성 옹알이를 시작한 9개월부터 종단 관찰 을 시작하였기 때문에 구개열 아동의 음절성 옹알이의 산출 시작
시기를 살펴보기에는 제한적이다. 따라서 음절성 옹알이가 일반적 으로 출현하기 시작하는 4-6개월 또는 그 이전부터 초기 발성 발달 을 살펴보는 것이 필요하다.

현재까지 이루어진 대부분의 국내외 초기 발성 연구는 실험실이 나아동의 가정에서 수집된 한 시간 미만의 짧은 발화 샘플을 분석 하였다. 낮선 환경이나 검사자와 함께 한 자료수집은 아동의 초기 발성 발달현황을 살펴보는 데 대표성이 떨어지고 제한적인 정보를 주고 있다. 그러므로 자연스런 환경에서 충분한 시간 동안 아동의 발달현황을 대표할 수 있는 샘플을 수집하여 발성 발달을 자세히 살펴보는 것이 필요하다. 본 연구는 LENA를 이용하여 구개열과 일 반아동의 가정에서 12 시간 이상 연속녹음된 발화 샘플을 이용하 여 4-6개월부터 19-21개월까지 음절성 옹알이를 살펴보고자 한다. 특히 말-언어장애 진단과 상관관계가 높아 임상적으로 중요한 음 절성 옹알이의 시작 시기에 초점을 맞추어서 아동의 초기 발성 발 달패턴을 종단적으로 살펴보고자 한다.

\section{연구방법}

\section{대상자}

본 연구는 (구순)구개열 아동 9명과 일반 아동 9명을 대상으로 하였다. 두 집단을 모두 남아 5 명, 여아 4 명으로 구성하여 성비를 일 치시켰으며 생후 4-6개월부터 연구에 참여하였다. 구개열 집단은 일측성 구순구개열 3 명, 양측성 구순구개열은 2 명, 구개열 4 명으로 구성되었다. 18 개월에 구개성형술을 받은 1 명을 제외하고 모든 구 개열 아동은 11-12개월에 구개성형술을 받았다. 또한 9명의 구개열 아동 중 6 명은 적어도 한 번 이상의 중이염 병력을 보였다. 일반아 동은 주양육자의 보고에 따라 출생전-중-후와 발달상의 문제가 없 었던 아동으로 구성하였다.

\section{자료수집}

자료수집은 구개성형술 이전인 4-6개월에 시작하여 3-6개월 간 격을 두고 총 4 회기에 걸쳐 이루어졌다. 음절성 옹알이의 출현 시기 이고 구개성형술 이전에 해당하는 전반부는 3 개월 간격으로 수집 하였다. 후반부는 구개성형술 후 1-2개월 이내에 한 회기 수집하였 으며, 수술 후 충분한 회복과 적응시간을 두고 발성 발달을 살펴보 기 위해서 6 개월 후에 4 번째 자료를 수집하였다. 예를 들어 한 아동 이 생후 4 개월에 첫 번째 자료를 수집하였다면 두 번째는 3 개월 후 인 7개월에 실시하였으며, 세 번째는 6개월 후인 13 개월에 실시하였 고 마지막 자료수집은 6 개월 후인 19개월에 실시하였다. 18 개월에 구개성형술을 받은 1명을 제외하고는 4-6개월, 7-9개월 자료는 모 
두 구개성형술 전에 수집된 것이고, 13-15개월과 19-21개월 자료는 구개성형술 이후에 수집된 자료로, 수술 전후의 초기 발성 발달패 턴을 관찰할 수 있도록 하였다. 18 명의 아동이 종단연구에 끝까지 참여했지만 건강상의 문제나 녹음기 고장으로 인해 7-9개월과 13-15개월에 각각 구개열 아동 1 명, 19-21개월에 일반아동 1 명의 음 원자료가 누락되었다. 발성 자료는 가정에서 LENA 녹음기(LENA Research foundation, Boulder, CO, USA)가 들어있는 조끼를 아동 에게 하루 동안 착용시켜 수집하였다. 회기마다 아동당 12-14시간 연속으로 녹음자료가수집되었다.

\section{자료분석}

분석자료는 먼저 LENA 녹음기로 수집된 자료를 자동처리하고 분석하는 LENA Pro 소프트웨어를 이용하여 한 회기(하루) 동안 아동이 산출한 전체 발성수를 확인하였다. 한 회기 전체 자료를 5 분 길이의 구간으로 나누어 아동의 발성수가 많은 순서로 20 개의 구 간을 선택하였다. 따라서 아동과 한 회기당 총 100 분의 녹음자료를 분석하였다. 암맹 분석을 위해 구개열 유무 및 월령을 포함하여 아 동 정보를 분석자에게 제공하지 않았으며, 아동의 초기 발성을 위 해 개발된 Action Analysis Coding and Training (AACT; Delgado, Buder, \& Oller, 2010) 프로그램을 이용하여 분석하였다. 자료 분석 은 Ha와 Oller (2019)와 동일한 방식으로 이루어졌다. Ha와 Oller (2019)에 기술된 바와 같이 약 20시간 이상 초기 발성에 대한 집중 적인 듣기 및 분석훈련을 받은 언어병리학전공 대학원생 2 인과 언 어치료사 1 인이 분석자로 참여하였다. 본 연구를 위한 발성 분석은 듣기 및 분석훈련 과정 중의 모든 측정치에서 검사자 간 신뢰도가 .80 이상을 보인 뒤에 시작하였다.

분석은 발성의 최소 리듬 단위로서 비트(beat)로 지각되는 음절 을 기본단위로 이루어졌으며, 울음, 웃음, 재채기, 딸꾹질 소리와 같 은 생리적인 소리는 분석에서 제외하였다. 12 개월 이후 자료에는 “낱말”로 정의할 수 있는 발화가 포함되어 있지만 보편적인 초기 발성의 분석방법에 따라 아동이 산출한 소리를 의미 있는 낱말과 발성(옹알이)으로 구분하지 않고 음절에 초점을 맞추어 모두 분석 하였다. 모든 음절을 (1) 적어도 하나의 자음과 모음으로 구성된 기 본 음절형(canonical syllable), (2) 활음을 포함한 음절, (3) 성문음 을 포함한 음절, (4) 자음-모음 구조가 포함되지 않은 비 기본 음절 형(non-canonical syllable) 중 하나로 분류하였다. AACT 프로그램 에 4 가지 음절유형별로 자판을 미리 지정하여 분석자가 녹음자료 를 들으면서 음절유형을 판단하여 해당 자판을 음절수만큼 누르 게 하였다. 분석은 기본적으로 청지각적인 판단에 의존하였지만, 음절수나 음절유형의 판단이 모호한 경우 $\mathrm{AACT}$ 프로그램의 음원
파형과 스펙트로그램에 나타난 음향학적 특성을 보완적으로 참조 하여 최종 분석하였다. Figure 1은 AACT 프로그램의 음원파형과 스펙트로그램에 나타난 기본음절형 2개로 구성된 발성의 예를 보 여주고 있다. 아동의 발성을 4 가지 음절유형으로 나눈 후 전체 음 절에서 자음과 활음이 포함된 음절의 비율을 살펴보기 위해서 음 절성 옹알이비율(canonical babbling ratio)을 구하였다. 활음은 우 리말에서 자음이 아니지만 상후두 조음기제의 움직임이 동반되어 자음과 유사한 조음 및 음성특성을 보이기 때문에 활음이 포함된

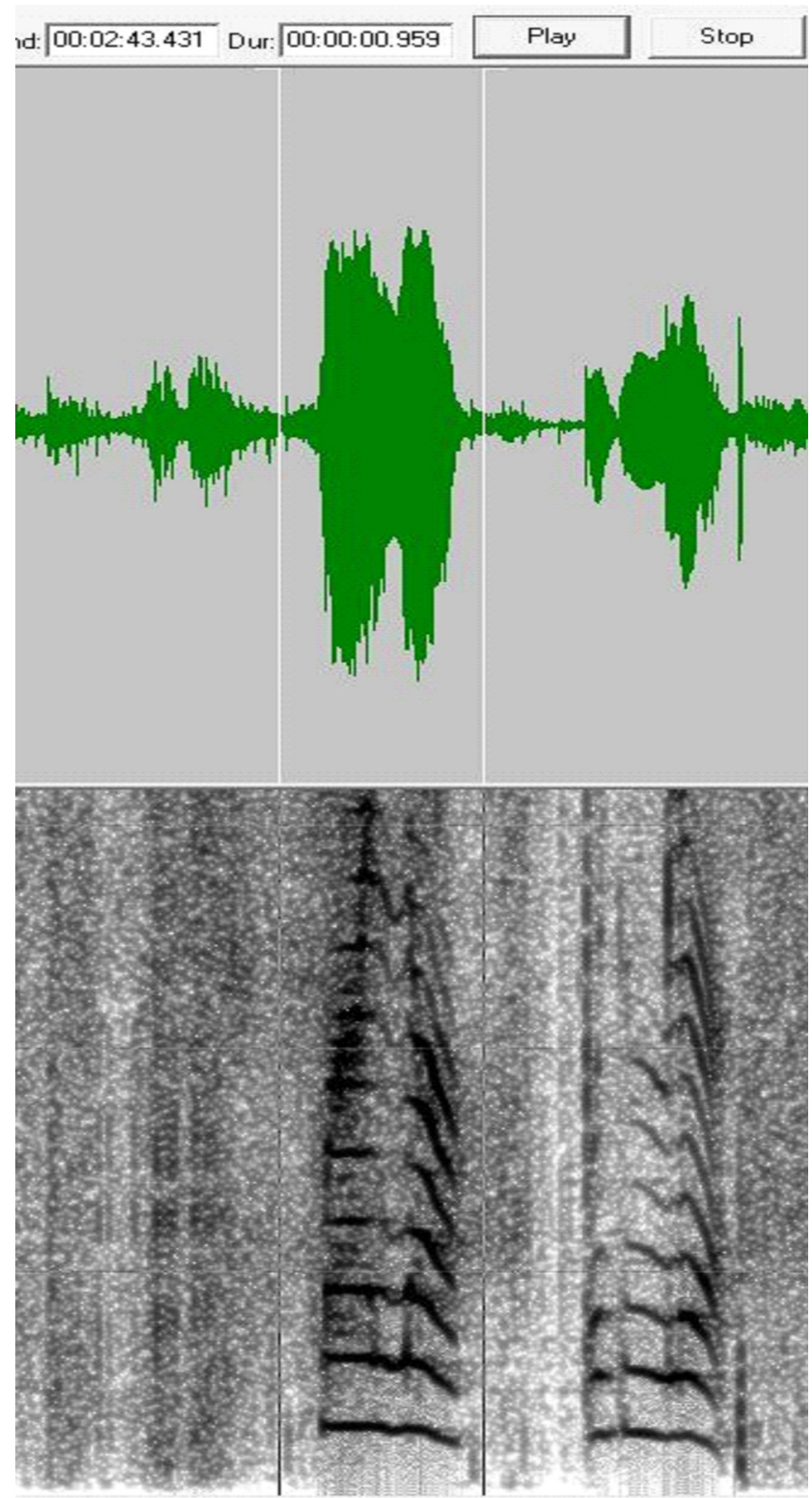

Figure 1. Example of a waveform and a spectrogram on the Action Analysis Coding and Training program. The waveform and spectrogram between the bars indicate two canonical syllables. 
음절은 기본음절형에 포함하여 음절성 옹알이비율을 산출하였다. 또한 활음이 포함된 음절을 제외하고 음절성 옹알이만을 토대로 진음절성 옹알이비율(true canonical babbling ratio)도 구하였다.

\section{통계 분석}

통계 처리는 SPSS version 22.0 프로그램을 사용하였다. 표본수 가 비교적 적어 비모수검정을 실시하였다. 월령별 집단 간 차이를 살펴보기 위해서는 Mann-Whitney U-test를 실시하였고, 집단별 월령에 따른 변화를 살펴보기 위해서는 Friedman's ANOVA를 한 후 사후검정으로 Wilcoxon test를 실시하였다. 대표값으로 중앙값 과 범위를 살펴보았으며 모든 유의수준은 $p<.05$ 로 설정하였다.

\section{연구결과}

\section{총 발성 수}

4 회기에 걸쳐 수집된 종단자료에서 각 회기당 관찰된 총 발성수 를 Table 1에 제시하였다. 총 발성수는 하루 중 잠자는 시간을 제외 한 12시간 동안 수집된 LENA 전체 자료에서 확인된 발성수를 의 미한다. Mann-Whitney $U$-검증 결과, 총 발화수는 4-6개월, 7-9개
월, 13-15개월, $19-21$ 개월의 4 회기 모두에서 집단 간 유의미한 차이 를 보이지 않았다. 두 아동 집단이 월령이 증가함에 따라 총 발성수 의 변화가 있는지 살펴본 결과, 구개열 아동은 월령에 따라 총 발성 수에 유의한 변화가 없었다. 하지만 일반아동은 월령에 따라 총 발

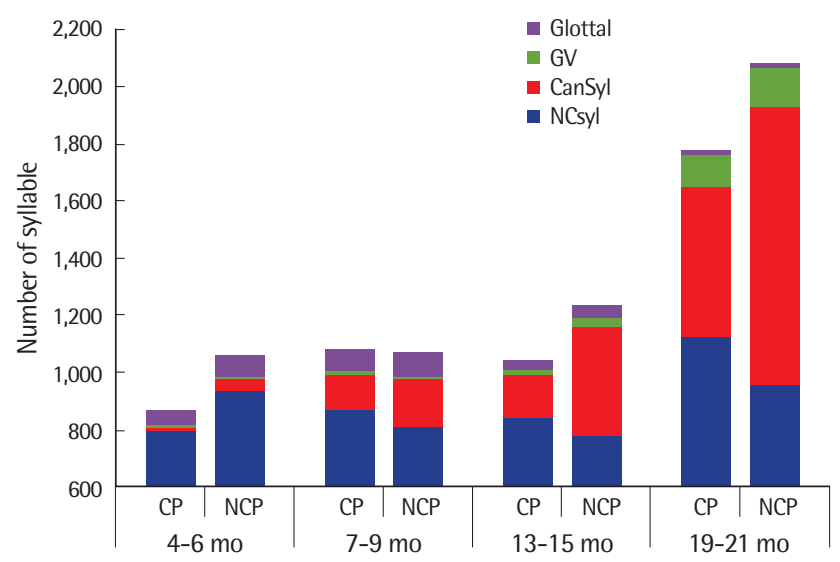

Figure 2. Number of total syllable and each type of syllables in the two groups across the observed times.

$\mathrm{CP}=$ children with cleft palate; $\mathrm{NCP}=$ children without cleft palate; $\mathrm{NCsyl}=$ noncanonical syllables; Cansyl=canonical syllables; GV= syllables with glide; GIstop = syllables with glottal.

Table 1. Number of infant vocalizations from each recording session

\begin{tabular}{|c|c|c|c|c|c|c|c|c|}
\hline & \multicolumn{2}{|c|}{$4-6$ mo } & \multicolumn{2}{|c|}{$7-9 \mathrm{mo}$} & \multicolumn{2}{|c|}{$13-15 \mathrm{mo}$} & \multicolumn{2}{|c|}{$19-21$ mo } \\
\hline & $\mathrm{CP}(\mathrm{N}=9)$ & $\mathrm{NCP}(\mathrm{N}=9)$ & $\mathrm{CP}(\mathrm{N}=8)$ & $\mathrm{NCP}(\mathrm{N}=9)$ & $\mathrm{CP}(\mathrm{N}=8)$ & $\mathrm{NCP}(\mathrm{N}=9)$ & $\mathrm{CP}(\mathrm{N}=9)$ & $\mathrm{NCP}(\mathrm{N}=8)$ \\
\hline $\begin{array}{l}\text { Number of infant } \\
\text { vocalization }\end{array}$ & $1,200(583-1,935)$ & $821(262-1,403)$ & $1,271(612-2,189)$ & $1,050(438-2,123)$ & $1,109(547-2,144)$ & $1,078(351-2,058)$ & $1,332(196-3,612)$ & $1,814(769-3,856)$ \\
\hline
\end{tabular}

Values are presented as median (range).

$\mathrm{CP}=$ children with cleft palate; $\mathrm{NCP}=$ children without cleft palate.

Table 2. Number of each type of syllables and total syllables in vocalization

\begin{tabular}{|c|c|c|c|c|c|c|c|c|}
\hline \multirow{2}{*}{ Syllable types } & \multicolumn{2}{|c|}{ 4-6 mo } & \multicolumn{2}{|c|}{$7-9 \mathrm{mo}$} & \multicolumn{2}{|c|}{$13-15 \mathrm{mo}$} & \multicolumn{2}{|c|}{$19-21 \mathrm{mo}$} \\
\hline & $\mathrm{CP}$ & NCP & $\mathrm{CP}$ & NCP & $\mathrm{CP}$ & NCP & $\mathrm{CP}$ & $\mathrm{NCP}$ \\
\hline Canonical syllables & $8(0-74)$ & $20(7-204)$ & 87 (8-325) & $107(21-615)$ & $123.5(10-391)$ & $344(123-748)$ & $423(127-1,644)$ & $726(225-2,666)$ \\
\hline Ratio (\%) & 1.78 & 3.25 & 9.07 & 13.94 & 15.13 & 29.91 & 27.01 & 42.52 \\
\hline Syllables with glides & $0(0-19)$ & $2(0-47)$ & $4(0-57)$ & $8(1-29)$ & $13(0-28)$ & $24(0-56)$ & $54(0-267)$ & $119.5(7-285)$ \\
\hline Ratio (\%) & 0.44 & 0.84 & 1.05 & 0.78 & 1.43 & 2.27 & 5.05 & 6.02 \\
\hline Syllables with glottals & $47(11-117)$ & 48 (22-297) & $50.5(0-389)$ & $27(16-252)$ & $43(1-97)$ & $34(3-109)$ & $15(5-92)$ & $16.5(0-70)$ \\
\hline Ratio (\%) & 9.86 & 6.76 & 6.82 & 8.14 & 3.80 & 4.13 & 1.13 & 1.42 \\
\hline Non-canonical syllables & $\begin{array}{c}731 \\
(143-1,365)\end{array}$ & $\begin{array}{c}769 \\
(575-1,945)\end{array}$ & $\begin{array}{c}776.5 \\
(421-1,588)\end{array}$ & $\begin{array}{c}845 \\
(531-1,072)\end{array}$ & $\begin{array}{c}867 \\
(350-1,687)\end{array}$ & $\begin{array}{c}778 \\
(549-1,046)\end{array}$ & $\begin{array}{c}958 \\
(703-2,266)\end{array}$ & $\begin{array}{c}812.5 \\
(453-1,773)\end{array}$ \\
\hline Ratio (\%) & 87.92 & 89.15 & 83.06 & 77.14 & 79.65 & 63.69 & 66.81 & 50.05 \\
\hline Total syllables & $\begin{array}{c}907 \\
(260-1,412)\end{array}$ & $\begin{array}{c}838 \\
(663-2,453)\end{array}$ & $\begin{array}{c}933 \\
(457-2,032)\end{array}$ & $\begin{array}{c}1,043 \\
(596-1,534)\end{array}$ & $\begin{array}{c}934 \\
(524-2,126)\end{array}$ & $\begin{array}{c}1,303 \\
(762-1,952)\end{array}$ & $\begin{array}{c}1,546 \\
(847-3,332)\end{array}$ & $\begin{array}{c}1,612 \\
(700-4,747)\end{array}$ \\
\hline
\end{tabular}

Values are presented as median (range).

$\mathrm{CP}=$ children with cleft palate; $\mathrm{NCP}=$ children without cleft palate. 
성수가 유의하게 차이가 있었는데 $\left(\chi^{2}=9.750, p=.021\right)$, 사후검정 결 과 일반아동은 4-6개월보다 19-21개월에 유의하게 많은 발성수를 산출하였다 $(p<.05)$.

\section{총 음절수와 음절유형별 수}

한 회기의 LENA 녹음자료에서 발성빈도가 높은 20 개의 5 분 구 간(총 100 분)을 선택하여 분석한 총음절수와 4 가지 음절유형별 수 와 비율에 대한 결과는 Table 2 와 Figure 2 와 같다. 총음절수는 4 가 지 음절유형 수의 총 합에 해당하고 음절유형별 비율은 전체 음절 수에서 각 음절유형이 차지하는 비율이다. 4 개월에서 21 개월까지 의 연구관찰기간 동안 구개열 아동과 일반아동은 모두 4 가지 음절 유형 중 비기본음절형이 가장 빈번하게 산출되기는 하였으나, 월령 이 증가할수록 기본음절형과 활음이 포함된 음절의 수가 증가하 는 추세를 보였다.

4 회기별로 집단 간 차이가 있는지 살펴보기 위해 유의성 검증 결 과, 총 음절수는 4 회기 모두에서 집단 간 유의미한 차이를 보이지 않았다. 음절유형별로 집단 간 차이가 있는지 살펴본 결과, 4 가지 음절유형 중 기본음절형만이 13-15개월에 집단 간 통계적으로 유 의한차이를 보였다 $(U=11.00, p=.016)$.
집단별로 월령에 따른 변화를 살펴본 결과, 일반아동은 총 음절 수에서 월령에 따른 유의미한 차이가 없었으나 구개열 아동은 월령 에 따른 유의미한 차이가 관찰되었다 $\left(\chi^{2}=8.314, p=.040\right)$. 사후검 정 결과 구개열 아동은 19-21개월에 4-6개월과 13-15개월보다 유의 하게 많은 음절수를 산출하였다 $(p<.05)$. 또한 4 가지 음절유형별로 각 집단의 월령에 따른 변화를 살펴본 결과, 일반아동은 기본음절 형 $\left(\chi^{2}=20.55, p<.001\right)$ 과 활음을 포함한 음절 $\left(\chi^{2}=12.57, p=.006\right)$ 은 유의하게 증가하였고, 성문음을 포함한 음절 $\left(\chi^{2}=8.25, p=.041\right)$ 은 유의하게 감소하였다. 구개열 아동은 기본음절형 $\left(\chi^{2}=15.51\right.$, $p=.001)$ 과 활음을 포함한 음절 $\left(\chi^{2}=9.70, p=.021\right)$ 이 유의한 증가 를 보였다. 비기본음절형은 두 집단 모두 월령에 따른 유의한 차이 가 없었다. 사후분석 결과, 일반아동과 구개열 아동 모두 기본음절 형은 4 회기 간 모두 서로 유의하게 차이가 나, 4 개월에서부터 21개 월에 걸쳐 기본음절형은 점진적으로 꾸준히 증가하는 것으로 나타 났다 $(p<.05)$. 활음을 포함한 음절은 구개열 아동과 일반아동 모두 에게서 4-6개월, 7-9개월, 13-15개월보다 19-21개월에 유의하게 증 가하였고, 일반아동은 더불어 7-9개월보다 13-15개월에 유의하게 많은 활음을 포함한 음절을 산출하였다 $(p<.05)$. 성문음을 포함한 음절은 일반 아동에게서만 유의한 차이가 나타났는데 사후분석

Table 3. CBR and TCBR (unit: \%)

\begin{tabular}{|c|c|c|c|c|c|c|c|c|c|c|}
\hline & \multirow{2}{*}{ Child no. } & \multirow{2}{*}{ Gender } & \multicolumn{2}{|c|}{$4-6$ mo } & \multicolumn{2}{|c|}{$7-9 \mathrm{mo}$} & \multicolumn{2}{|c|}{$13-15 \mathrm{mo}$} & \multicolumn{2}{|c|}{$19-21 \mathrm{mo}$} \\
\hline & & & CBR & TCBR & CBR & TCBR & CBR & TCBR & CBR & TCBR \\
\hline \multirow[t]{10}{*}{$\mathrm{CP}$} & 1 & $\mathrm{~F}$ & 0 & & 9 & 8 & $51^{*}$ & 48 & $49 *$ & 37 \\
\hline & 2 & $\mathrm{~F}$ & 2 & 2 & $\mathrm{~N} / \mathrm{A}$ & $\mathrm{N} / \mathrm{A}$ & 1 & 1 & $22^{*}$ & 22 \\
\hline & 3 & $M$ & 3 & 2 & 4 & 4 & 13 & 12 & $28 *$ & 20 \\
\hline & 4 & $M$ & 0 & 0 & 2 & 2 & 11 & 11 & $26^{*}$ & 24 \\
\hline & 5 & $M$ & 0 & 0 & 14 & 14 & $27^{*}$ & 23 & $15^{*}$ & 15 \\
\hline & 6 & $\mathrm{~F}$ & 0 & 0 & 4 & 4 & 11 & 8 & $36^{*}$ & 33 \\
\hline & 7 & $M$ & 1 & 1 & $25^{*}$ & 25 & $16^{*}$ & 15 & $22^{*}$ & 14 \\
\hline & 8 & $\mathrm{~F}$ & 10 & 8 & $16^{*}$ & 10 & $\mathrm{~N} / \mathrm{A}$ & $\mathrm{N} / \mathrm{A}$ & $33^{*}$ & 29 \\
\hline & 9 & $M$ & 3 & 3 & 6 & 6 & 2 & 2 & $57^{*}$ & 49 \\
\hline & Median & & 1 & 1 & 8 & 7 & 12 & 12 & 28 & 24 \\
\hline \multirow[t]{10}{*}{ NCP } & 1 & $\mathrm{~F}$ & 1 & 1 & 14 & 14 & $41^{*}$ & 38 & $53^{*}$ & 40 \\
\hline & 2 & $M$ & 9 & 8 & $19 *$ & 19 & $31^{*}$ & 28 & $42^{*}$ & 32 \\
\hline & 3 & $M$ & 13 & 7 & 10 & 10 & $21^{*}$ & 20 & $38 *$ & 37 \\
\hline & 4 & $M$ & 2 & 1 & 3 & 3 & $39 *$ & 35 & $44^{*}$ & 34 \\
\hline & 5 & $M$ & 3 & 2 & $18^{*}$ & 18 & $19^{*}$ & 16 & $33^{*}$ & 32 \\
\hline & 6 & $\mathrm{~F}$ & 1 & 1 & $16^{*}$ & 15 & $40^{*}$ & 39 & $67^{*}$ & 64 \\
\hline & 7 & F & 1 & 1 & 6 & 5 & $35^{*}$ & 35 & $62^{*}$ & 56 \\
\hline & 8 & $F$ & 3 & 3 & $43^{*}$ & 41 & $40^{*}$ & 35 & N/A & $\mathrm{N} / \mathrm{A}$ \\
\hline & 9 & $M$ & 4 & 4 & 3 & 2 & $23^{*}$ & 22 & $47^{*}$ & 44 \\
\hline & Median & & 3 & 2 & 14 & 14 & 35 & 35 & 46 & 39 \\
\hline
\end{tabular}

Each bold and asterisk indicate a child who achieved the canonical babbling stage at the observed time. $\mathrm{CBR}=$ canonical babbling ratio; $\mathrm{TCBR}=$ true canonical babbling ratio; $\mathrm{CP}=$ children with cleft palate; $\mathrm{NCP}=$ children without cleft palate; $\mathrm{N} / \mathrm{A}=$ loss of $\mathrm{LENA}$ audio data. 
결과 다른 월령대에 비해 19-21개월에 유의하게 감소한 것으로 나 타났다 $(p<.05)$.

\section{음절성 옹알이의 비율}

4 회기에 걸쳐 두 집단과 구개열, 일반아동 개인별로 음절성 옹알 이비율과 진음절성 옹알이비율을 구한 결과를 Table 3에 제시하였 다. 먼저 4-6개월, 7-9개월, 13-15개월, 19-21개월에 걸쳐 두 집단의 음절성 옹알이비율의 중앙값을 살펴보면 구개열 아동은 각각 $1 \%$, $8 \%, 12 \%, 28 \%$ 였다. 일반아동은 4 회기에 걸쳐 $3 \%, 14 \%, 35 \%, 46 \%$ 로 나타나 7-9개월 이후에 구개열 아동보다 기본음절 비율이 두드 러지게 증가하는 것이 관찰되었다. 두 집단 모두 진음절성 옹알이 비율도 음절성 옹알이비율과 거의 비슷한 발달패턴을 보였다. 4 회 기별로 집단 간 차이가 있는지 통계적으로 살펴본 결과, $13-15$ 개월 $(U=12.00, p=.021)$ 과 $19-21$ 개월 $(U=12.00, p=.021)$ 에 음절성 옹알 이비율에 유의미한 차이를 보였다. 마찬가지로 진음절성 옹알이비 율도 13-15개월 $(U=12.00, p=.021)$ 과 19-21개월 $(U=11.00, p=.016)$ 에 모두 집단 간 유의미한차이를 보였다 $(U=11.00, p=.016)$.

집단별로 월령에 따른 음절성 옹알이와 진음절성 옹알이의 비율 을 살펴본 결과, 구개열과 일반 집단 모두 월령에 따라 음절성 옹알 이(구개열 집단: $\chi^{2}=13.11, p=.004$; 일반 집단: $\chi^{2}=22.20, p<.001$ ) 와 진음절성 비율(구개열 집단: $\chi^{2}=12.43, p=.006$; 일반 집단: $\chi^{2}=$ $20.55, p<.001)$ 이 유의한 차이를 보였다. 사후분석 결과, 구개열 아 동은 4-6개월과 7-9개월, 13-15개월, 19-21개월 간과 7-9개월과 19-21 개월 간에 유의한 차이를 보였다 $(p<.05)$. 일반아동은 모든 월령 간 비교에서 유의한 차이를 보여 $(p<.05), 4-21$ 개월에 걸쳐 관찰한 4 회 기 동안 꾸준히 유의하게 음절성 옹알이와 진음절성 옹알이 비율 이 증가하는 것으로 나타났다.

음절성 옹알이의 시작 시기와 관련해서 음절성 옹알이비율이 $15 \%$ 이상인 아동의 수와 비율을 확인하였다(Table 4). 4-6개월에 는 구개열과 일반아동 집단에서 아무도 음절성 옹알이비율이 $15 \%$ 이상을 보이지 않았다. 7-9개월에는 2명의 구개열 아동과 4 명의 일 반아동이 $15 \%$ 이상을 보였다. 13-15개월에는 일반아동 9명 모두 $15 \%$ 이상을 보여 모두 음절성 옹알이 단계로 진입한 것으로 나타

Table 4. Number of children who achieved the canonical babbling stage across the observed time

\begin{tabular}{lcccc}
\hline & $4-6 \mathrm{mo}$ & $7-9 \mathrm{mo}$ & $13-15 \mathrm{mo}$ & $19-21 \mathrm{mo}$ \\
\hline $\mathrm{CP}$ & $0(0)$ & $2(22.2)$ & $3(33.3)$ & $9(100)$ \\
$\mathrm{NCP}$ & $0(0)$ & $4(44.4)$ & $9(100)$ & $9(100)$ \\
\hline
\end{tabular}

Values are presented as number (\%).

$\mathrm{CP}=$ children with cleft palate; $\mathrm{NCP}=$ children without cleft palate.
난 반면에 구개열 아동은 3명만이 음절성 옹알이 단계에 진입하였 다. 19-21개월에는 모든 구개열 아동이 $15 \%$ 이상의 음절성 옹알이 비율을 보여 두 집단의 모든 아동이 음절성 옹알이에 도달한 것으 로 나타났다.

\section{논의 및 결론}

본 연구는 아동의 가정에서 12 시간 이상 연속녹음된 발화 샘플 을 토대로 구개열 아동과 일반아동을 대상으로 4-6개월부터 19-21 개월까지 초기 발성 발달패턴을 종단적으로 살펴보고자 하였다. 특히 말-언어발달과 높은 상관관계를 보이기 때문에 임상적으로 중요한음절성 옹알이의 시작 시기에 초점을 맞추어 살펴보았다. 먼 저 하루 동안 수집된 자료에서 아동의 총 발성수를 확인하고 아동 의 발성빈도가 가장 높은 100 분의 구간을 발췌하여 분석하였다. 아동의 총 발성수와 음절수를 비교한 결과, 두 측정치 모두 관찰기 간 동안 두 집단 간 유의미한 차이를 보이지 않았다. 선천적인 장애 를 가진 아동의 경우 발성의 양이 적은 경우가 많아, 음절성 옹알이 의 시작 시기, 음절구조와 유형과 더불어 발성의 양은 이후 발달하 는 말과 언어능력과 밀접한 관련이 있다고 보고되고 있다(Belardi et al., 2017; Iyer, Denson, Lazar, \& Oller, 2016). 하지만 구개열 아동 의 경우 발성의 양은 다른 선천적인 장애에 비해 연구결과의 일관 성이 떨어진다. 일부 연구에서는 구개열 아동이 일반아동보다 적은 수의 발성을 산출한다고 보고하였으나(Chapman, 1991; Philips \& Kent, 1984), 또 다른 연구에서는 일반아동과 유의미한 차이가 없 다고 보고하였다(Chapman et al., 2001). 구개열 아동의 발성수에 관한 기존 선행연구에서는 아동이 낮선 검사자가 함께 한 가운데 수집된 한 시간 미만 또는 약 100 발화 정도의 짧은 발성을 토대로 이루어졌다. 반면에 본 연구에서는 아동의 자연스런 언어환경에서 하루 동안 수집한 자료를 분석한 점을 고려한다면 본 연구의 결과 가 좀 더 타당하다고 할 수 있다. 특히 아동의 발성빈도가 가장 높 은 100 분의 구간의 분석뿐만 아니라 한 회기에 수집된 12 시간 이상 의 전체 자료에서 분석한 총 발성수도 집단 간 차이가 없었다. 또한 월령이 증가할수록 일반과 구개열 아동 모두 각각 총 발성수와 총 음절수 면에서 유의한 증가를 보여 성장하면서 발성의 양이 증가함 을 보여주었다. 아동은 옹알이를 내면서 말산출과 관련된 청각적, 조음기제의 움직임과 촉각적 피드백 시스템을 발달시키고 소리산 출 연습을 한다. 따라서 일반적으로 발성의 양이 많을수록 이러한 말 발달 과정이 원활하게 이루어지고 있음을 의미하기 때문에 일 반아동과 비교해 구개열 아동이 발성의 양적인 측면에서 차이가 없 다는 결과는 말 발달에 있어서 긍정적인 면이다. 
그러나 구개열 아동의 발성과 음절수는 일반아동과 유의미한 차 이를 보이지 않았지만 기본음절형의 수와 전체 음절에서 차지하는 비율면에서는 집단 간 유의한 차이를 보였다. 특히 7-9개월 이후에 일반아동이 구개열 아동보다 기본음절 비율이 두드러지게 증가하 면서 13-15개월과 19-21개월 음절성 옹알이비율과 진음절성 옹알 이비율이 유의하게 높았다. 두 집단의 월령에 따른 음절유형별 변 화를 자세히 살펴보면, 일반아동과 구개열 아동 모두 공통적으로 기본음절형과 활음을 포함한 음절은 유의한 증가를 보였지만 성문 음을 포함한 음절은 일반아동에게서만 유의한 감소가 관찰되었다. 성문음을 포함한 음절은 상후두 조음기제를 본격적으로 사용하 여 소리를 만들어 내기 전에 아동이 일반적으로 많이 산출하는 발 성유형이다. 일반아동은 다른 월령대에 비해 19-21개월에 유의한 감소를 보였는데 이는 이 시기에 성문음 산출이 줄고, 자음과 모음 이 포함된 기본음절이 증가하고 기본음절이 포함된 낱말을 활발하 게 산출하는 발달적인 특성을 반영한다고 할 수 있다. 반면에 구개 열 아동은 관찰기간 동안 성문음을 포함한 음절수에 변화가 없었 는데 이는 이후 낱말산출 단계에서 구개열 특유의 말 문제인 보상 조음으로 발전될 가능성이 있다. 따라서 음절성 옹알이 단계 이후 에도 성문음을 포함한 음절이 감소하지 않는 구개열 아동에 대한 보다 세심한 관찰이 필요할 것이다.

연구결과를 종합해 보면 일반 아동에 비해 구개열 아동은 단순 히 발성의 양이 적은 것이 아니라 빠른 전이구간을 보이면서 완전 공명핵, 자음 같은 소리가 포함된 음절성 옹알이 발달이 지연됨을 알 수 있다. 더욱이 한 명을 제외한 모든 구개열 아동이 구개성형술 을 받은 13 개월 이후에 일반아동과 음절성 옹알이 비율 차이가 더 두드러지게 나타났다. 13 개월 이후에는 일반 아동은 이미 모든 아 동이 음절성 옹알이를 $15 \%$ 이상으로 산출하고 안정된 음절성 옹 알이 산출을 토대로 의미 있는 낱말을 산출하기 시작하였지만 $60 \%$ 이상의 구개열 아동은 여전히 음절성 옹알이 단계에도 진입하 지 못하고 있었다. 13-15개월은 구개성형술을 받은 지 3개월 이내로 수술 후에 회복하고, 변화된 기제에 적응을 해야 하는 점을 고려한 다면 음절성 옹알이비율이 낮은 것은 당연할 수 있다. 하지만 19-21 개월 이후에도 지속적으로 일반아동보다 음절성 옹알이비율이 낮 은 점은 이후 초기 말-언어발달 지연과 연결될 가능성이 높으므로 주목해야 한다. 18 개월 이후부터 일반적으로 표현어휘수와 자음 목록이 빠르게 증가하고 2어 조합이 나타나면서 말-언어발달이 비 약적으로 이루어지는 시기이다. 반면에 구개열 아동은 이 시기에 수술 후 회복 및 적응기간, 반복적인 중이염 등의 부정적인 조건들 로 인해 말-언어발달이 느리게 진행되어 음절성 옹알이비율의 집단 간차이가 더 커졌다고 할수 있다.
음절성 옹알이의 시작 시기를 조작적으로 정의한 기존 선행연구 에 따라 음절성 옹알이비율이 $15 \%$ 이상인 아동을 확인하였다. 일 반적으로 음절성 옹알이가 시작된다고 보고되는 4-6개월에는 일 반아동을 포함해서 모든 아동이 음절성 옹알이비율이 $15 \%$ 에 미치 지 못하였다. 7-9개월부터 음절성 옹알이비율이 $15 \%$ 이상인 아동 이 나타나면서 2 명의 구개열 아동과 4 명의 일반아동이 $15 \%$ 이상을 보였다. 13-15개월에는 일반아동 9명 모두 $15 \%$ 이상을 보여 모두 음절성 옹알이 단계로 진입한 것으로 나타난 반면에 구개열 아동 은 3 명만이 음절성 옹알이 단계에 진입하였다. 음절성 옹알이가 전 체 음절에서 차지하는 비율이 $15 \%$ 이상인 것을 기준으로 사용할 경우 분명히 초기 발성과 말 발달이 느린 아동을 구분해 주기는 하 나 음절성 옹알이의 시작 시기를 살펴보기에는 다소 엄격한 기준 이 될 수 있다. 즉 이미 음절성 옹알이 단계에 진입한 아동을 이전 단계에 있다고 판단할 가능성이 있다. 본 연구와 동일한 방법으로 분석한 Ha와 Oller (2019) 연구에서도 마찬가지로 4-6개월 아동의 음절성 옹알이비율이 평균 $4.7 \%$ 로 모든 아동이 $15 \%$ 이하로 산출 하였다. $15 \%$ 의 기준을 제안한 Lynch 등(1995)은 실험실 상황에서 수집한 20 분 정도의 발화 샘플을 기초로 하고 있다. 따라서 아동의 가정에서 하루 동안 수집한 발화 샘플에서 발화수가 높은 100 분 을 선택하여 분석한 본 연구상황에서는 음절성 옹알이 시작 시기 에 대한 다른 기준이 더 타당할 수 있겠다. 음절성 옹알이의 시작 시 기가 임상적으로 말-언어문제를 예측하는 중요한 지표이고, LENA 녹음기를 이용하여 자연스런 언어환경에서 아동의 발성 자료를 충 분히 수집할 수 있게 된 점을 고려한다면 음절성 옹알이의 시작 시 기를 결정하는 기준에 대해 보다 체계적인 연구가 필요하다. 가정에 서 아동의 보호자가 음절성 옹알이 산출을 지각할 수 있는 수준에 서 실제 아동의 음절성 옹알이의 산출 비율이 어떠한지 살펴볼 필 요가 있겠다.

본 연구는 4-6개월에서부터 19-21개월까지, 음절성 옹알이가 출 현하기 전부터 일정한 간격을 두고 아동의 초기 발성의 발달을 종 단적으로 살펴보았다는 점에서 의미가 있다. 하지만 아동마다 종단 연구에 참여하기 시작한 시기가 달라 발달적으로 비슷한 특성을 보이는 월령끼리 묶어서 살펴보았고, 3 개월 또는 6 개월의 간격을 두 고 종단자료가 수집된 점은 아동의 초기 발성의 발달을 세밀하게 관찰하기에는 큰 제한점이다. 따라서 추후 지속적인 자료수집을 통 해 0-20개월에서 모든 월령대의 아동 자료를 균형 있게 포함하여 일반 및 구개열 아동의 전반적인 초기 발성 발달에 대한 대표적인 자료와 언어이전기 아동을 평가할 때 참조할 수 있는 기준을 제시 해야 할 것이다.

본 연구결과는 궁극적으로 구개열 아동을 대상으로 언어이전기 
부터 초기 발성을 토대로 말-언어문제를 예측하고 보다 적극적으 로 조기 중재를 제공해야 함을 강조하고 있다. 특히 구개성형술을 받고 회복기가 지났음에도 불구하고 말 발달이 지속적으로 느린 경우가 많으므로 음절성 옹알이의 산출 시기와 양을 토대로 중재 대상자를 일찍 확인할 필요가 있다. 또한 본 연구는 구개열 아동의 발성과 초기 말 발달을 위해 어떠한 자극과 촉진을 제공해야 할지 에 대한 방향성을 제시한다. 옹알이 유형과 상관없이 단순히 소리 산출을 촉진하기보다는 자음이 포함된 음절형 옹알이 산출을 촉 진해야 한다. 일부 아동은 초기 발성 단계에서부터 보상조음을 발 달시키는 경우가 있기 때문에(Chapman et al., 2001)/ㅂ/,/ㄷ/와같 은 소리를 포함하면서 입술이나 혀 끝의 움직임을 강조하는 '발성 놀이(vocal play)'가 유용하다.

\section{REFERENCES}

Belardi, K., Watson, L. R., Faldowski, R. A., Hazlett, H., Crais, E., Baranek, G. T., ... \& Oller, D. K. (2017). A retrospective video analysis of canonical babbling and volubility in infants with Fragile X syndrome at 9-12 months of age. Journal of Autism and Developmental Disorders, 47(4), 1193-1206.

Chapman, K. L. (1991). Vocalizations of toddlers with cleft lip and palate. The Cleft Palate-Craniofacial Journal, 28(2), 172-178.

Chapman, K. L., Hardin-Jones, M., Schulte, J., \& Halter, K. A. (2001). Vocal development of 9-month-old babies with cleft palate. Journal of Speech, Language, and Hearing Research, 44(6), 1268-1283.

Cobo-Lewis, A. B., Oller, D. K., Lynch, M. P., \& Levine, S. L. (1996). Relations of motor and vocal milestones in typically developing infants and infants with Down syndrome. American Journal of Mental Retardation, 100(5), 456-467.

Delgado, R. E., Buder, E. H., \& Oller, D. K. (2010). Action analysis coding and training (AACT). Miami, FL: Intelligent Hearing Systems.

Ertmer, D. J., Young, N. M., \& Nathani, S. (2007). Profiles of vocal development in young cochlear implant recipients. Journal of Speech, Language, and Hearing Research, 50(2), 393-407.

Ha, S. (2018). Profiles of vocal development in Korean children with and without cleft palate. Clinical Linguistics \& Phonetics, 32(1), 46-69.

Ha, S., \& Oller, D. K. (2019). Canonical babbling in Korean-acquiring infants at 4-9 months of age. Communication Sciences \& Disorders, 24(1), 1-8.

Iyer, S. N., Denson, H., Lazar, N., \& Oller, D. K. (2016). Volubility of the human infant: effects of parental interaction (or lack of it). Clinical Linguistics \& Phonetics, 30(6), 470-488.

Kim, M., \& Ha, S. (2013). Longitudinal study of early vocalization development in toddlers with and without cleft palate from 6 to 18 months of age. Communication Sciences \& Disorders, 18(2), 223-234.

Lee, C. C., Jhang, Y., Relyea, G., Chen, L. M., \& Oller, D. K. (2018). Babbling development as seen in canonical babbling ratios: a naturalistic evaluation of all-day recordings. Infant Behavior and Development, 50, 140-153.

Lynch, M. P., Oller, D. K., Steffens, M. L., Levine, S. L., Basinger, D. L., \& Umbel ,V. (1995). Onset of speech-like vocalizations in infants with Down syndrome. American Journal on Mental Retardation, 100(1), 68-86.

Nathani, S., Ertmer, D. J., \& Stark, R. E. (2006). Assessing vocal development in infants and toddlers. Clinical Linguistics \& Phonetics, 20(5), 351-369.

Oller, D. K. (2000). The emergence of the speech capacity. Mahwah, NJ: Lawrence Erlbaum Associates.

Philips, B. J., \& Kent, R. D. (1984). Acoustic-phonetic descriptions of speech production in speakers with cleft palate and other velopharyngeal disorders. In N. Lass (Ed.), Speech and language: advances in basic research and practice (pp. 113-167). New York, NY: Academic Press. 


\section{국문초록}

\section{구개열 아동과 일반아동의 음절성 옹알이의 시작 시기}

\section{하승희}

한림대학교 언어청각학부, 한림청각언어연구소

배경 및 목적: 음절성 옹알이의 출현은 생후 1년 동안 일어나는 말 발달에서 가장 중요한 이정표이고 말-언어발달상의 문제를 예측하 는 주요 요인이다. 본 연구는 아동의 가정에서 하루 동안 수집된 자료를 토대로 구개열과 일반아동의 음절성 옹알이의 발달을 종단적으 로 살펴보고자 하였다. 방법: 구개열과 일반아동 각각 9 명을 대상으로 LENA 녹음기를 이용하여 생후 4 개월에서부터 21 개월에 걸쳐 일 정한 간격으로 초기 발성 자료를 4 회기 수집하였다. 하루 동안 수집된 각각의 회기 자료에서 아동 발성이 가장 높은 5 분 길이의 구간 20 개를 선택하여 아동과 회기당 총 100 분의 녹음자료를 들으면서 분석자가 발성을 판단하였다. 총 음절수, 음절유형수, 음절성 옹알이와 진음절성 옹알이 비율을 구하여 월령에 따라 집단 간 유의한 차이가 나타나는지 살펴보았다. 결과: 관찰기간 동안 총 음절수는 집단 간 차이를 보이지 않았다. 13-15개월에 구개열 아동이 일반아동보다 기본 음절수가 유의하게 적었다. 13-15개월과 19-21개월에 음절성 옹 알이와 진음절성 옹알이 비율에서 집단 간 유의한 차이가 나타났다. 논의 및 결론: 본 연구는 구개열 아동이 음절성 옹알이를 늦게 산 출하고, 구개성형술을 받은 이후에도 일반아동과 비교해 음절성 옹알이 비율이 유의미하게 낮음을 보여주었다. 본 연구는 궁극적으로 구개열 아동을 위한 조기 중재의 중요성을 강조하고 있다.

핵심어: 음절성 옹알이, 시작, 구개열, 자연스런 환경, 종단 연구

본 논문은 한림대학교 교비 학술연구과제(No. HRF-201906-007)에 의해 수행되었음.

\section{참고문헌}

김민영, 하승희(2013). 6-18개월 구개열 영유아와 일반 영유아의 발성 발달에 관한 종단연구. Communication Sciences \& Disorders, 18(2), 223-234. 하승희, D. Kimbrough Oller (2019). 4-9개월 한국 아동의 음절성 옹알이. Communication Sciences \& Disorders, 24(1), 1-8.

\section{ORCID}

하승희(https://orcid.org/0000-0003-2133-3720) 